\title{
THE INFLUENCE OF EMOTIONAL INTELLEGENCE AND JOB STATISFACTION TO ORGANIZATIONAL COMMITMENT
}

\author{
Hasanuddin Harun \\ Faculty of Psychology, University of Medan Area, Indonesia \\ hasanuddinbinharun@gmail.com
}

\begin{abstract}
This study aims to determine the effect of emotional intelligence and job satisfaction on organizational commitment. The research method used in this research is quantitative approach with expost facto method, which means researching the phenomenon that has happened. Subject of research that is Teacher in State Junior High School 3 Medan, amounting to 65 people. Methods of data analysis research using multiple regression analysis method, which aims to see the effect of emotional intelligence and job satisfaction on organizational commitment. The result of statistical analysis by using multiple regression shows simultaneously emotional intelligence and job satisfaction influence organizational commitment seen from determinant coefficient value $R^{2}=0.499$ with $p=0.000<0.050$, which means its influence equal to 49,9\%. For emotional intelligence to organizational commitment seen from the value of determinant coefficient $R^{2}=0.357$ with $p=0.000$ $<0.050$, which means influence of $35.7 \%$. and job satisfaction on organizational commitment seen from the determinant coefficient value $R^{2}=0.520$ with $p=0.000<0.050$, which means the influence of $52 \%$.
\end{abstract}

Keyword: Emotional Intelligence, Job Satisfaction, Organizational Commitment, Development, Ability.

\section{INTRODUCTION}

The world of education in Indonesia continues to experience changes and developments since decades ago that have had a significant impact on human life. With various approaches, many studies have proved this case. Susanto (1998) states that in the era of Indonesia's 2nd national awakening today we must be able to predict, understand and harmonize science and technology that develops today and future in all aspects of life. To be able to carry out the necessary quality human resources and insightful and able to compete in a healthy way in all aspects. Goleman (1999) explains that a person's ability to do a job is always influenced by the atmosphere and emotional state. Goleman explains more about the ability of individuals to do something related to the stability of one's emotions in adjusting itself to the changes and the development of the times.

The ability and intelligence of the individual to act must use all the intelligence he possesses well. The concept of emotional intelligence offered by Goleman can help improve work performance individually or in groups or work teams and so affect the success of the organization (Butcher and Harvey, 1998). In harmony with that, Harahap (2000) declares qualified, achieving and high-quality human resources required in the present and future, ie (i) good language skills, (ii) able to use technology tools, (iii) proficient in communication, (iv) healthy cooperation, (v) having creativity and flexibility, (vi) good in leading, (vii) adhering to ethics and morals, (viii) having a vision, innovation and high morale.

In order to overcome the challenge of shifting the humanitarian paradigm, as it is known, the 21 st century promises a sophisticated era as a result of the great development of science and technology derived from continuing social change in all aspects of life, therefore it requires human resources who have the ability to think and ability to use cutting-edge technology tools (Sidi, 2000). Goleman (2000) states that man has two intellectual thoughts and emotional minds. According to him, these two intelligences are very helpful in improving the quality of self and other human resources. Ignoring one of these capabilities causes many individuals to experience personal problems or even associate with environments such as the organizations they work with or with other communities. 
Recognizing that the role of teachers is a link between the education system and human resources, while the impact of education innovation programs conducted through teachers (Medley 1982). The role of educational institutions is definitely challenging and requires more careful planning. Therefore, educational institutions through teachers create knowledgeable, talented and skilled people relevant to the times and contribute to the achievement of educational goals in Indonesia. This shows the profession of teachers is a profession that not only has a functional burden but also a moral burden on society and the future of the nation.

The profession referred to here is the work or activity undertaken by the teacher and become a source of financial or life that requires expertise, skills, creativity and innovation in accordance with the value or norm of quality or norm by requiring education education profession. This requirement, as teachers in Indonesia, should work together in a quality working group to solve complex educational problems and find strategies for educational and teaching reforms in line with national education objectives, to face future challenges.

Blacburn \& Lawrence (1995) states that educational institutions are the world's social organizations that have an important role in preparing and improving human resources to occupy certain positions, applying culture to new generations to prepare individuals to be more skilled, creative, innovative and able to criticize society, and able to produce and explore science and technology. As a structured organization, educational institutions have a value or a high standard of proficiency in a person's academic skills. This means one of the factors that must be considered in educational institutions is individual teachers as a professional human resources. Generally, the skills, professions in the expertise of each masingguru obtained from educational institutions and the environment.

The key is whether qualified educators will or will not be determined by the influence of individual teachers to continue to learn and develop themselves and adapt to environmental influences. Commitment to the organization is one of the key perspectives on employee behavior towards the organization. According to Mayer \& Allen (1990) organizational commitment is the main focus in theoretical descriptions of the factors that affect commitment and its influence on the organization.

Commitment to the organization benefits individuals to meet their needs in terms of the stability of staff work against the organization. Scholl (1981) study found that committed staff will continue to work diligently even though the atmosphere within the organization is either stimulating or not encouraging. According to Steers (1977) through the study of commitment to the organization greatly affect the creativity of staff towards their careers. Therefore, it is important to examine how staff are committed to the organization and what factors influence their commitment. According to Mowday, Porter \& Steers (1982), and Geoje \& Jones (1996), individual factors and individual external factors can affect a person's level of commitment to the organization. In line with Goleman's (1995) study, it is recommended that organizations that wish to have competitiveness depend on good relationships between staff members who have their own knowledge and skills. From individual factors researchers try to explore from the perspective of emotional intelligence on the work commitment of an organization.

According to Goleman $(1995,1999,2000)$ emotional intelligence is an important part of a person's life, whether it's a private group or a workgroup. Therefore, individuals working in organizations tend to have no task conflict. Therefore, it is possible that teachers with high emotional intelligence tend to have high commitment, because individuals know who they are, always maintain good relationships with others and try to be the best workers. Emotional intelligence is the ability of a person to be considered a "meta-abillity" that acts as a source of intelligence that the individual needs to use all other intelligence and other possessive skills effectively. The importance of this capability, for meta's ability among staffers in shaping and adapting individual competencies to their working conditions such as independent learning and independent learning. The advantage is to help improve individual and group performance and excellence and affect organizational effectiveness (Goleman, 1995, 1999, 2000).

Cherniss (2001) explains that the emotional intelligence factor of an employee can determine the effectiveness of commitment to the organization. Correspondingly, Carson \& Carson (1998) found that emotional intelligence is an important part of growing commitment to the organization. Based on the model, someone who is committed to his work is a person with a smart emotion, those who are intelligent in their emotions can motivate and control their own emotions, visionaries when making decisions, understand and empathize with the psychological needs of others and engage in good social relationships. 
Other studies such as those of Abraham (1999), Campbell (2000) Grandley (2000), Menges (1999) and Pasanen (2000) found that emotional intelligence is an important factor and has a significant relationship with the attitudes and effectiveness of a person in the organization. Nevertheless, it has been described above that one's work commitment to the organization is not influenced by individual factors but is also influenced by individual external factors. Therefore, the individual external factors in this study is not the work factor and organizational factors objectively but the perspective or perception of a person on the job and the organization is often referred to as job satisfaction factors.

Job satisfaction factors of teachers are suggested as an external factor of individuals who have an important role in increasing organizational commitment to educational institutions. Teacher job satisfaction is the attitude of teachers to work and organization based on experience of the environment in which they work.Worchel \& Woehr (1998) job satisfaction contributes significantly to the commitment to the organization displayed by staff working within the organization. Viewing teachers in educational institutions has a different character from staff working in institutions outside educational institutions. The question is whether the same results will be obtained from teachers working in educational institutions in Indonesia?

Job satisfaction of teachers in the profession in educational institutions in Indonesia has an important role because teachers have the potential to affect many people. Unhappy teachers show an ineffective commitment to the organization. Railly, Chatman \& Caldwell (1991) states that job satisfaction is seen as an individual attitude, built from the perspective or perception of work and organization. The Dessler (1985) study links job satisfaction with one's emotions to his work and is associated with the ability to attain one of the most important job requirements phases. In light of this, seeing emotional intelligence is a learned and constructive skill, while job satisfaction can also be enhanced by individuals, as well as policy-makers of educational organizations in improving the work performance of individuals or groups within an organization, an early step to improving organizational commitment among teachers are in an Indonesian educational institution. The description above illustrates how important emotional intelligence and job satisfaction are owned by teachers to be able to commit in educational organizations. This is the underlying researchers want to examine the Influence of Emotional Intelligence and Job Satisfaction against Organizational Commitment to Teachers in SMA Negeri 3 Medan.

\section{RESEARCH PURPOSES}

This study aims to determine the effect of emotional intelligence and job satisfaction on organizational commitment. The objective condition in this study is emotional intelligence is a thing that must be owned by teachers and emotional intelligence is not in the job description teacher but is an important competence possessed by the teacher in order to maximize its role. The low teacher work satisfaction resulted in the teacher doing the switching of educational institution so as to make the teacher become ineffective in carrying out its function. The low organizational commitment of the teachers is due to the low emotional intelligence of teachers and the satisfaction of the teachers themselves, whereas organizational commitment is a very important thing for a teacher who is a stakeholder in the educational institution.

\section{RESEARCH METHODS}

This research uses quantitative research method with expost facto approach. The population in this research is the teacher in SMA Negeri 3 Medan. The sampling technique was done by total sampling, then the sample was obtained amounted to 65 people. Data analysis used multiple regression analysis. Intrusmen research used as a variable measurement alata-shaped scale psychology developed by researchers by way of guiding aspects and indicators of each variable. The measurement instruments in this research are: The scale of emotional intelligence used is the scale developed by Goleman in Noriah, et al (2004) with Cronbach's Alpha reliability index of 0.914. The employment satisfaction scale used is a scale developed by (Smith, et al in Toelis, 2005) with Cronbach's Alpha0.800 reliability index. The scale of organizational commitment used is the Affective Continuity and Normative Commitment Scales (ACNCS) model developed by Allen and Mayer (1990) with Cronbach's Alpha reliability index of 0.830 . 


\section{RESEARCH RESULTS AND DISCUSSION}

Based on the analysis result using multiple regression known that there is positive influence of emotional intelligence and job satisfaction to organizational commitment. It is seen from the results of multiple regression analysis using SPSS program is from the determinant coefficient value $\mathrm{R}^{2}=0.499$ with $\mathrm{p}=0.000<0.050$, artinyasemakin emotional intelligence and job satisfaction hence the higher commitment of the organization. The determinant coefficient value $\mathrm{R}^{2}=0.499$ means the effective contribution of emotional intelligence and job satisfaction collectively to organizational commitment of $49.9 \%$. Furthermore, there is also an influence of emotional intelligence on organizational commitment seen from the value of determinant coefficient $\mathrm{R}^{2}=0.357$ with $\mathrm{p}=0.000<0.050$, meaning that the higher the emotional intelligence the higher the organizational commitment. The determinant coefficient value $\mathrm{R}^{2}=0.357$ means the effective contribution of emotional intelligence to organizational commitment of $35.7 \%$.

Emotional intelligence has the personality traits that every teacher needs to succeed in his career. Identification of the level of emotional intelligence provides valuable information to teachers in evaluating self-efficacy and further into efforts to improve the quality of human resources. The importance of emotional intelligence in improving personal or group performance and organizational commitment has been evidenced by the results of empirical studies such as foreign research by Goleman, 1995, 1999, Carson \& Carson 1998, Carson \& Salovey 1998, Mayer 1999, 2000, 2001; Tapia 1999, Carson \& Salovey 2000 Cooper 1997; and Dulewicz \& Higgs 2000). Local studies in Malaysia (Noriah et al., 1999, 2002, 2003, 2004; Zuria, 2005; Syed Najamuddin Bin Syed Hassan, 2004; Mohd Najib Ghafar, 2000; Mohammad Tajuddin Nursalam Bin Sima Abdullah, 2000 and Iskandar 2009).

Research also supports the results of research conducted Copper (1997) showed that emotional intelligence affects individuals and organizations in terms of how one decides, organizational dynamics and value of life are most satisfying. In fact, Copper (1999) explains that individuals with high emotional intelligence are said to be more successful in their work, have strong individual relationships, good leadership and effective and have good personal health so that more committed in the organization. This suggests that the results of this study add to the khasana to reinforce that the importance of a teacher has a good emotional intelligence and high organizational commitment to the agency where the work amid the phenomenon of teacher welfare which is increasingly improved and paid special attention by the government. Not only emotional intelligence is an important factor in improving the organizational commitment of teachers in an educational institution but also the job satisfaction of the teacher is also an important determinant factor. It is known that the effect of job satisfaction on organizational commitment is seen from the determinant coefficient value $\mathrm{R}^{2}=0.520$ with $\mathrm{p}=0.000<0.050$, meaning that the higher the job satisfaction the higher the organizational commitment. The determinant coefficient value $\mathrm{R}^{2}=0.520$ means the effective contribution of job satisfaction to organizational commitment by $52 \%$. Teachers who feel satisfied with their work or so-called teacher job satisfaction have a considerable contribution in determining a teacher willing to commit in the organization in this case the education institution that is equal to $52 \%$.

According to Locke (1990) that job satisfaction is a pleasant feeling arising from the perceived perception of the worker about something or thing being observed. His research on satisfaction of rewards such as salary, promotion, and recognition depends on whether they are performing fairly and fairly. Similarly, attitudes toward work depend on a person's suitability in factors that help achieve career goals. A worker will be satisfied with the individual at the place of work as a leader, supervisor, subordinate, coworker and management can all help to alleviate the achievement of career goals. In line with Hackham \& Oldham (1980) workers who find satisfaction in work will be more committed to the organization where he works. So also with a teacher who has a high job satisfaction will give a high influence also on his commitment in the organization where he worked the educational institution. This study has proven that the emotional intelligence of a good teacher and job satisfaction of a high teacher have a high influence also on the organizational commitment of the teacher at the place he worked. 


\section{CONCLUSION}

Based on the data analysis, it is concluded that there is a positive influence between emotional intelligence and job satisfaction on the organizational commitment of Master. Where the influence of emotional intelligence on organizational commitment Teachers seen from the value of determinant coefficient $\mathrm{R}^{2}=0.357$ with $\mathrm{p}=0.000<0.050$, meaning that the higher the emotional intelligence the higher the commitment of the organization. The determinant coefficient value $\mathrm{R}^{2}=0.357$ means the effective contribution of emotional intelligence to organizational commitment of $35.7 \%$. It is known that the effect of job satisfaction on organizational commitment is seen from the determinant coefficient value $\mathrm{R}^{2}=0.520$ with $\mathrm{p}=0.000<0.050$, meaning that the higher the job satisfaction the higher the organizational commitment. The determinant coefficient value $\mathrm{R}^{2}=0.520$ means the effective contribution of job satisfaction to organizational commitment by $52 \%$.

Further simultaneously there is a positive influence of emotional intelligence and job satisfaction on organizational commitment. It is seen from the results of multiple regression analysis using SPSS program is from the determinant coefficient value $R^{2}=0.499$ with $p=0.000<0.050$, artinyasemakin emotional intelligence and job satisfaction hence the higher commitment of the organization. The determinant coefficient value $\mathrm{R}^{2}=0.499$ means the effective contribution of emotional intelligence and job satisfaction collectively to organizational commitment of $49.9 \%$.

\section{REFERENCE}

Abraham, R. 1999. The Impact Of Emotional Dissonance On Organizational Commitment And Intention To Turnover. The Journal Of Psychology 133 (4): 441-445. Teachers In Malaysia. Disertasi Ph.D. Louisiana State Universiti.

Abraham, R. 2000. Emotional Intelligence In Organizations: A Conceptualizational Commitment And Intention To Turnover. The Journal Of Psychology 133(4)441-455.

Allen, N. J. \& Meyer, J.P. 1990. The Measurement And Antecedent Of Affective, Continuance And Normative Commitment To The Organization. Journal Of Occupational Psychology 63: 1-18.

Baron, R. 1998. The Emotional Quotient Inventory (Eq-i): Technicalmanual. Toronto: Multi Health Systems.

Baron, R. \& Parker 2000. The Handbook Of Emotional Intelligence: Theory, Development, Assessment, And Application At Home, School, And In The Workplace. San Francisco: JosseyBass.

Blackburn, R.T., \& J.H. Lawrence. 1995. Faculty At Work: Motivation, Expectation, Satisfaction. Baltimore: The John Hopkins University Press.

Butcher, D. \& Harvey, P. 1998. Meta-Ability Development: A New Concept For Career Management. Career Development International 3 (2):75-78.

Carson, K.D \& Carson, P.P 1998. Career Commitment, Competencies, And Citizenship. Journal Of Career Assessment 6 (2): 195-208.

Chatman, J. A. 1991. Matching People And Organizations: Selection And Socialization In Public Accounting Firms. Administrative Science Quarterly, 36, 459-484.

Cherniss, C. 1998. Social And Emotional Learning For Leaders. Educational Leadership. 55(7)26-28.

Dessler. G. 1985. Human Behaviour Improving Performance At Work. Virginia: Rostom Publishing Company Inc.

Erawati Toelis. 2005. Pengaruh Iklim Kerjasama, Motivasi Kerja Dan Gaya Kepemimpinan Pengetua Terhadap Kepuasan Kerja Guru. Tesis Dr. Fal. Universiti Kebangsaan Malaysia, Bangi.

Goleman, D. 1995. Emotional Intelligence New York: Bantam Books.

Goleman, D 1999. Emotional Competence. Executive Excellence 16 (4): 19.

Goleman, D. 2000. Emotional Intelligence: Issues In Paradigm Building. Dlm. Cherniss, C. \& Goleman, D. The Emotionally Intelligent Workplace, Hlm. 27-44. San Francisco: JosseyBass.

Iskandar. 2008. Penagaruh Kecerdasan Emosi Dan Kepuasan Kerja Keatas Komitmen Pekerjaan Dan Komitmen Organisasi Di Kalangan Pensyarah Pendidikan Tinggi Daerah Jambi Indosesia. Tesis Ph.D Universiti Kebangsaan Malaysia.

Locke, E. A \& Latham, G. P. 1990. Work Motivation And Satisfaction: Light At The End Of The Tunnel. Psychological Science 1(4):240-246. 
Mowday, Porter \& Steers (1982) Employee Organization Linkages: The Psychology Of Commitment, Absen Teeism And Tumove New York: Academics Press

Mayer, J., Allen, N.J. 1993. Commitment To Organizations And Occupation: Extension And Test Of a Three-Component Conceptualization. Journal Of Applied Psychology. 78(4): 538-551.

Mayer, J.D. \& Allen, N. 1997. Commitment In The Workplace: The Theory, Research And Application. Thousand Oaks: Sage.

Mayer, Jd., Caruso, D.R. 2000. Emotional Intelligence As Zeitgeist, As Personality, And As a Mental Ability. Dlm Bar-On, R. \& Parker, J.D.A. (Pnyt). The Handbook Of Emotional Intelligence: Theory, Development, Assessment, And Application At Home, School, And In The Workplace, Hlm. 92 - 117. San Francisco: Jossey - Bass.

Medley, D. M. 1982. Teacher Effectiveness, Dlm Buku Encyclopedia Of Educational Research, Oleh H. Mitzel, N.Y.II;Free Press, 1894-1903.

Mohd. Azhar Hj. Yahya. 2004. Kecerdasan Emosi Ke Atas Komitmen Kerjaya, Komitmen Organisasi, Kepuasan Kerja Dan Tingkah Laku Warga Organisasi

Mottaz, C.J. 1988. Determinants Of Organizational Commitment. Human Relations 41(6):467-482.

Noriah Mohd. Ishak, Siti Rohayah Dan Syed Najamuddin Syed Hassan. 2004. Hubungan Antara Faktor Kecerdasan Emosi, Nilai Kerja Dan Prestasi Kerja Di Kalangan Guru Maktab Rendah Sains Mara. Journal Teknologi. 39(E): 75-82.

Reyes, P. 1992. Organizational Commitment Of Teachers. Dlm Reyes, P. (Pnyt). Teachers And Their Workplace, Hlm 87 -99. Newbury Park, Ca: Sage.

Shin, H. \& Reyes, P. 1991. Teacher Commitment And Job Satisfaction: Which Comes First? Chicago: American Educational Research Association. Eric Document Reproduction Service No. Ed 338-596.

Steer, R.M. 1977. Antecedents And Outcomes Of Organizational Commitment. Administrative Science Quarterly 22: 57-74.

Susanto, A.B. 1998. Tinjauan Pendidikan Tinggi Dalam Memasuki Melenium Ketiga: Renungan Beberapa Aspek Pembaharuan Dunia Pendidikan. Universiti Atma Jaya Yogyakarta Indonesia Memasuki Melenium Ketiga. Yogyakarta. Andi Offset. Pp. 77-88. 